\title{
EATING DURING ADOLESCENCE AND ITS RELATIONS WITH ADOLESCENT HEALTH
}

\author{
Julyana Gall da Silva1, Maria Luiza de Oliveira Teixeira², Márcia de Assunção Ferreira ${ }^{3}$
}

\footnotetext{
${ }^{1}$ Master's student in Graduate Program at Anna Nery School of Nursing (EEAN), Universidade Federal do Rio de Janeiro (UFRJ). CNPq grantee. Rio de Janeiro, Rio de Janeiro, Brazil. E-mail: julyanagall@hotmail.com

2 Ph.D. in Nursing. Adjunct Professor, Fundamental Nursing Department, EEAN/UFRJ. Rio de Janeiro, Rio de Janeiro, Brazil. E-mail: mlot@uol.com.br

${ }^{3}$ Ph.D. in Nursing. Full Professor, Fundamental Nursing Department, EEAN/UFRJ. CNPq researcher. Rio de Janeiro, Rio de Janeiro, Brazil. E-mail: marciadeaf@ibest.com.br
}

\begin{abstract}
This study aims to identify the contents of teenagers' representations about eating and to analyze the relations established among feeding, weight and health. Social Representations Theory was applied in combination with the Convergent-Care Method. The participants were 27 teenagers of both genders between 13 and 19 years old who attended a group of young people from an evangelical church. The thematic content analysis organized categories that clarified the contents of the representations about healthy and unhealthy eating, which influence the occurrence of diseases and overweight. Although typical of teenagers, fast food is not healthy. It was concluded that teenagers know about healthy food and the problems deriving from bad eating habits; thinness represents health and obesity is related to disease; and the food culture of adolescence influences their practices.
\end{abstract}

DESCRIPTORS: Feeding. Psicology, social. Nursing care.

\section{ALIMENTAÇÃO NA ADOLESCÊNCIA E AS RELAÇÕES COM A SAÚDE DO ADOLESCENTE}

RESUMO: Objetivou-se identificar os conteúdos das representações de adolescentes sobre a alimentação e analisar as relações estabelecidas entre a alimentação, o peso e a saúde. Aplicou-se a Teoria das Representações Sociais em associação com o Método da Pesquisa Convergente-Assistencial. Participaram 27 adolescentes de ambos os sexos com idade entre 13 e 19 anos, que frequentam um grupo de jovens de uma igreja evangélica. A análise de conteúdo temática organizou categorias que elucidaram os conteúdos das representações sobre a alimentação saudável e não saudável, que influenciam na ocorrência de doenças e sobrepeso. As comidas de preparação rápida não são saudáveis, mas são típicas da adolescência. Concluiu-se que os adolescentes têm conhecimentos sobre alimentação saudável e os problemas decorrentes de maus hábitos alimentares; magreza representa saúde e a obesidade se relaciona à doença; e a cultura alimentar própria da adolescência influencia suas práticas.

DESCRITORES: Alimentação. Psicologia social. Cuidado de enfermagem.

\section{ALIMENTACIÓN EN LA ADOLESCENCIA Y RELACIONES CON LA SALUD DEL ADOLESCENTE}

\begin{abstract}
RESUMEN: Se objetivo identificar los contenidos de las representaciones de adolescentes sobre la alimentación y analizar las relaciones establecidas entre la alimentación, el peso y la salud. Se aplicó la Teoría de las Representaciones Sociales en asociación con el Método de la Investigación Convergente-Asistencial. Participaron 27 adolescentes de ambos los sexos con edad entre 13 y 19 años, que frecuentan un grupo de jóvenes de una iglesia evangélica. El análisis de contenido temático organizó categorías que aclararon los contenidos de las representaciones sobre la alimentación saludable y no saludable, que influencian en la ocurrencia de enfermedades y sobrepeso. Las comidas de preparación rápida no son saludables, pero son típicas de la adolescencia. Se concluyó que los adolescentes tienen conocimientos sobre alimentación saludable y los problemas decurrentes de males hábitos alimentares; delgadez representa salud y la obesidad se relaciona a la enfermedad; la cultura alimentar propia de la adolescencia influencia sus prácticas.
\end{abstract}

DESCRIPTORES: Alimentación. Psicología social. Atención de enfermería. 


\section{INTRODUCTION}

Nowadays, the analysis of eating during adolescence requires a critical and objective look at this cultural phenomenon. For nursing, in addition, it involves the mobilization of knowledge that permits the implementation of care, mainly of health education, to turn the adolescents into subjects-agents of their own healthcare, with a view to health promotion and disease prevention related to aspects of unhealthy dietary practices.

Adolescence is frequently associated with a human development period marked by biological and mental transformations that cause concerns and suffering. The emergence of sexuality and the difficulty to establish one's own health are some of the elements associated with this phase. According to the World Health Organization (WHO), this phase involves the chronological time between 10 and 19 years of age and is divided in two subphases: from 10 to 14 years and from 15 to 19 years. The phase from 10 to 14 years is characterized as a period of high nutritional demand, as it is in this phase that the changes of puberty start. ${ }^{1}$

In this interval, nutrition plays a fundamental role, as it outlines favorable growth and development conditions. In that sense, food consumption, knowledge and representations about healthy eating during adolescence have received great attention, mainly considering the relations between inappropriate dietary habits and the development of certain diseases in adult age.

Healthy eating arouses representations that remit to the understanding of the social knowledge the subjects construct about this phenomenon that of eating. Thus, the intent is to discuss eating in the light of the Social Representations Theory (SRT), turning it into a research focus because of its social relevance, mainly in the group of adolescents. ${ }^{2}$

In SRT, both the subjects and objects are constituted in a relational process. Their study permits accessing the meanings the individual or collective subjects attribute to a research problem localized in their social and material context, and examining how the meanings are articulated with their sensitivity, their interests, their desires, their emotions and cognitive functioning. ${ }^{3}$

Eating is a broad social fact, as it connects the social and individual on the one hand and the physical (or physiological) and the mental on the other. ${ }^{4}$ Studies on eating as a social fact, however, are concentrated in the field of sociology, with analysis objects that differ from those desired in the health area, which aims to use these universes for intervention proposals. ${ }^{5}$

Eating is more than simply consuming food. It has the meaning of the personal, social and cultural relations that are involved in that act. The individual's eating culture is directly linked to that person's manifestation in society. Food is one of the basic requirements of human existence, and acquiring that food plays an important role in the formation of any culture. The methods of seeking and processing these food items are closely linked to a group's cultural and social expression. ${ }^{6}$

The disease process involves complex matters of psychological and social changes, in which the influence of the adolescent's environment is noteworthy in the formation of his character, thoughts and habits. In the contemporary society, adolescence is considered a phase characterized by the psychobiological, sociocultural and chronological dimensions involved in growth and development, which also result from political, historical and economic contexts. ${ }^{7}$

It is emphasized that the lack of knowledge about the adolescents' characteristics and the devaluation of their perceptions and meanings about health distance the nursing actions from the individual needs and care practices. Thus, they do not permit qualified care in terms of efficacy and the ability to solve the problems affecting the adolescents' health. $^{7}$

Knowing adolescents' representations about food matters to devise health promotion and education actions with a view to effectively reaching the group and mobilizing changes of habits, with a view to avoiding health complications in the adult phase.

To understand the social representation about healthy eating in a group of adolescents and its consequences in the adult phase, in this study, the contents of the social representations are explored through the application of concepts that sustain the SRT in the broad sense as, in this theory, the concept of representation has a more dynamic meaning, referring to the process through which the representations are elaborated 
and the knowledge structures are established. These representations are part of reality and are seen as belonging to the group. That is, they function collectively through interactions and behaviors. ${ }^{8}$

Hence, the existence of an external reality is not ignored, but it is defended that it will only be important to the extent of the subjects' social representation. This implies the production of meaning and transformation. The social representations are collective creations that are generated in and, at the same time, permit communication. ${ }^{9}$

In this interval, this study refers to the adolescents' knowledge about healthy eating, the representations of this practice and the relation between body weight, their own health and that of the people in their social group.

The objectives in this research were to identify the contents of adolescents' social representations about food in order to understand their practices and analyze the relations they establish between food, weight and health.

\section{METHOD}

A qualitative study was undertaken. The theoretical approach of the Social Representations (SRs) was adopted to explore the contents of the adolescents' knowledge about the object under analysis, associated with the Convergent-Care Research (CCR) Method. ${ }^{10}$

SSR should be developed at the place where the subjects' social relations take place, with a view to a creative synthesis of a simultaneous associative process between the research approach and practice. ${ }^{10}$ In addition, it requires the study subjects' active participation, as a research type whose development is closely related with the social situation and aims to find solutions to specific problems of the practice. ${ }^{11}$

The association between the theoretical framework of the Social Representations theory and CCR was possible because, in the light of the SRT, the knowledge implies practices; therefore, this theory allows the researcher to understand the reason for the subjects' actions, based on what they think about the object they were supposed to think about. The CCR acts with the subjects, exactly to problematize their practices with a view to better understanding them and realigning them, if that is the case.
The subjects were adolescents who attend a youth group that meets on Sundays at an evangelical church in Rio de Janeiro, between 13 and 19 years of age, who proposed to participate through the signing of an Informed Consent Form (ICF) and authorization by the legal caregivers when under age. The choice of the scenario is justified by the fact that the adolescents periodically have social contact during the group meetings and the family's participation in church activities, permitting greater cultural homogeneity in the group.

The inclusion criteria of the subjects were: adolescents between 10 and 19 years of age, according to the WHO classification, male and female, living in the city of Rio de Janeiro, with intact cognitive conditions and preserved verbal communication. Any subjects who did not fit into these criteria were excluded. The group consisted of 35 adolescents. Thirty of them complied with the inclusion criteria and 27 accepted to participate in the study, 15 of them female and 12 male.

The data were produced between February and March 2012, at the place where the weekly meetings were held, as that is the environment of relations and group meetings. Two approaches took place, the first of which was based on the presentation of the research and its objectives, after which a new meeting was scheduled to hold the interviews.

The instrument contained open questions related to themes like food, body weight and health, allowing the adolescents to expose their knowledge and doubts. They were asked to talk about their eating practices and the relation between weight and health in order to reveal their knowledge about food and health, based on scenes concretely experienced in their social group or family.

The production phase was developed through the application of the interview technique, in which the researcher dialogued with the adolescent and asked questions. This dialogue was recorded using an MPEG Audio Layer-3 (MP3) recorder. At the end of each interview, considering the obtained answers, the researcher and adolescent talked about eating, aiming for health education, and the latter received a folder with information about eating and health during adolescence. 
This conversation permitted clarifying doubts about the theme and providing orientations for the acquisition of healthy eating habits, with a view to achieving convergence between research and care, strengthening the health education measures previously proposed in the adolescent group. These measures were based on dietary heath, women's health and health education for hypertensive and diabetic patients. It was done at the end of the data production to avoid interference in the course of the subjects' thoughts when capturing their representations.

The data were analyzed through the application of thematic content analysis resources, ${ }^{12}$ constituting categories based on recurring themes in the discourse. The recording units representative of the themes constituted categories, and the semantic contexts of the words that gave meaning to the themes permitted accessing the contents and understanding the representations of the object, in this case eating during adolescence, searching its meanings and objectification. Objectification is defined as an imagining and structuring process that gives body to the conceptual schemes, reabsorbing the excess of significations, a necessary procedure in this process. ${ }^{13}$

This study is a sub-project linked to the integrated research project approved by the Research Ethics Committee at Anna Nery School of Nursing (EEAN) and the Teaching Hospital São Francisco de Assis (HESFA) at Universidade Federal do Rio de Janeiro (UFRJ), protocol n. 077/07, in compliance with National Health Council 196/96 on research involving human beings. Subjects under 18 years of age were asked to sign the assent term and parents and subjects over 18 years the informed consent term.

The subjects' anonymity was maintained with alphanumerical identification, in which $\mathrm{M}$ refers to male, $\mathrm{F}$ to female, followed by the number that indicated the order of the interviews.

\section{RESULTS AND DISCUSSION}

Adolescence is a phase marked by different modifications and by the construction of a social being through its daily relations and social groups. In this context, assessing the diet creates opportunities for intervention and health education measures to try and modify habits that can entail consequences for health during the adult phase.
In that sense, the discussion starts about the eating phenomenon and its meanings for adolescent health, based on its understanding, the elaboration of preventive educational approaches and the early identification of health problems in this phase.

\section{Contents of adolescents' representations about healthy eating}

\section{Meanings of healthy eating}

The change in the eating habits based on the reduction in high-calorie food consumption and the increased intake of fruit and vegetables is seen as a focus to maintain a healthy diet. ${ }^{14}$

Concerning the understanding of healthy eating for the adolescents, the interviewees' unanimously agreed when they relate it with the consumption of foods like vegetables, greens and cereals, justified by the fact that these are less fatty, following the same information pattern throughout the interview. In addition, the testimonies also reveal citations about sports and the reduced consumption of sweets, soft drinks and typical fast food items like hamburgers, pizza and crisps, which the adolescents objectify through the use of the term "crap".

Not eating that much crap, eating well, healthy foods so as not to cause health problems in the future, and practice sports too. Crap is fast food, drinking a lot of soft drinks, that kind of stuff (F01).

Eating vegetables frequently, not eating sweets that frequently so as not to get fat. Eating the calories she needs, not eating a lot of crap, reaching an average per day, always without exaggerating and heal thy foods like carbohydrates and proteins (M01).

Healthy eating is not only associated with physical exercise, there is also a lot of salad and things with protein, that kind of things (F02).

It is balanced eating, rich in all kinds of foods, ranging from greens, leaves, vegetables to cereals, cheese, that kind of things (F03).

For me it means having breakfast, lunch, dinner, always eating fruits, vegetables and a lot of protein, to get strong (M02).

When asked to self-assess the quality of their diet, the adolescents did not unanimously consider that they eat healthily, showing self-criticism with 
regard to their habits; 13 adolescents assumed that their diet is not aligned with what is recommended as healthy, 11 answered that their diet is partially healthy and only three said their diet is completely healthy.

No, because I do not usually eat greens, vegetables and I really eat a lot of fat (M03).

No, because my work does not allow me to have a better diet because I work on the streets, I am always rushing, so I eat a turnover and, sometimes, considering what we earn, which is the food ticket, not the meal ticket, you can only buy cookies, and we do not always have money to have a meal (M04).

More or less, because sometimes I eat heal thy good and, on most occasions, because the day is very busy I do not eat healthy things (F04).

I consider my diet partially healthy as I don't have time to eat the things I have to eat. Because of accumulating fat and increasing by body mass and I don't eat the foods I'd have to (M02).

Yes, because I avoid eating fat and things that are bad for my health (F05).

\section{Representations of a typical adolescent diet}

Not distanced from the typical diet in this phase, the intense consumption of fatty foods was witnessed, classified under the common term "crap", which combines a series of rapidly prepared foods that, in a way, give identity to the adolescents and are considered typical of this phase. This evidences the representation of the object as an influence on the adolescent health condition as, according to the adolescents, these foods are responsible for present and future health problems, increased body weight and difficulty to perform physical exercise seen as simple for the adolescents, such as working out and playing soccer.

It was also identified that eating well is related with less tasty foods than those called "crap", characteristic of fast food restaurants, represented as a typical environment for adolescents to attend. It is analyzed that eating is more focused on the pleasure of eating than on the nutritional value of the food. One eats for pleasure and not for what that food represents in nutritional terms. Not the nutritional value of the food, but the taste and the pleasure of eating are emphasized. ${ }^{6}$
Thus, when asking the adolescents if there are foods typical of the adolescence phase, 24 indicated the "crap", as the preferred foods are exactly those foods the adolescents themselves translated as opposed to the examples of a healthy diet, as these preparations are rich in fat, such as hamburger, pizza and crisps. A considerable number of justifications indicated a lack of time to eat well and the obligation to have meals in restaurants, as most of the day is spent outside the home.

Yes, hamburger and snacks. I have to eat on the street and quickly, that is all I have time to eat (F06).

Yes, because during adolescence you want to eat hamburger, pizza, that kind of things, but the right thing would be to eat rice, beans, that kind of things (F05).

Yes, hot dog, hamburger, crisps, that kind of fast food, you know? (M05).

\section{Eating, weight and health during adolescence}

\section{Relation among eating, weight and health for adolescents}

When discussing the influence of eating and their bodily health for the adolescents, 24 interviewees established this relation in their opinions and practices, demonstrating their comprehension of the topic. The content analysis of the testimonies clearly showed the critical look of those who eat ineffectively, in view of the adolescent representations of a healthy body, and what this grants them in their daily activities.

I think that yes because the person who eats well and does not eat crap, in the future that won't cause health problems, and the person who eats different kinds of crap will certainly have health problems (F01).

Perfectly, because you need energy and you can't get that much energy by eating snacks, those things. You need strength and foods with energy to provide you with, otherwise you might faint and get sick (M06).

Yes, because many people who have a heart problem, that is related to the fat the people have, so I think like, the more fat and fried foods the person eat, the more prone she gets to get like that (F14).

In another aspect, the body weight is directly connected with the type of food for the adolescents, considering that people who eat healthily, without exaggerating and with low-fat foods maintain their ideal weight and mostly represent 
leanness as health. This assessment was found in all adolescents.

In this context, eating is seen as a social activity that comprises the relation with the other and with the family, and the factors associated with eating influence the education, socialization, care delivery, the transmission of beliefs and values and, in general, the health and wellbeing of its elements. ${ }^{15}$

In the content analysis of the testimonies, all of the adolescents gave examples of people who represented some kind of health problem related to their weight as a consequence of their food, which shows the social representation of the context in which the adolescents live with their health perceptions.

In fact, the people are kind of uninformed because their weight is proportional to their height and you have to know how to control that and a short person cannot eat a lot, while a tall person has more mass to expand and can eat a bit more [...] (M06).

Those obese people who eat too much, a lot of crap too, I think it's strongly related. Many friends of mine are chubby and eat a lot of crap (F01).

If you eat things that make you fat you get fat, but if you try to eat good things you'll lose weight and live well. When my mother had me, she gained a lot of weight so she says she'll lose weight and is on a healthy $\operatorname{diet}(\mathrm{F} 07)$.

Not only the weight is characteristic of what you eat, people who eat wrong things gain weight and that's a problem. I know a person who was eating hamburger and pizza all the time, and didn't eat real food like rice, beans and salad, then she got fat and now when she cut that she was able to return to her normal weight (F02).

Yes, a little, only if you eat a lot of wrong things, a lot of calories and don't practice sports you tend to get obese. When I was younger, I used to eat a lot but I was skinny, and today I'm fatter but I play soccer, I walk from home to school and from school to home. My friend has already suffered from high triglycerides but I didn't see her eating a lot of crap, but she probably did to have that high level (M01).

At the same time, when analyzing the representation of the body weight with regard to people's health according to the adolescents, 19 adolescents consider the healthy status based on the stereotype of leanness, which represents the health ideal. In addition, the adolescents correlate the difficulty to exercise and perform simple daily activities with obesity and illnesses.

Yes, because in most cases, my friend, who is obese, gets ill, has more problems, but if she loses weight she can get well and be normal, but a chubby person can be healthy too (M01).

Yes, because heavy persons are less strong, they have more health problems and, although they eat a lot, they eat badly and do not have the nutrients their body needs (F06).

In the same sense, eight adolescents did not relate their weight with their health status, with different and comparative explanations, without any dependence between possible weight disorders and health. Therefore, the fact was justified by the metabolic bodily characteristics of each and by lifestyle, and not only by an inappropriate diet.

It depends. Some people we know are either very skinny or overweight, but their health is good, without any heart, breathing problems but, in most cases, these problems are caused by the diet and improvements also depend on that, and not only on whether she is fat or thin (M02).

No, because there are people of high weight and their health and cholesterol are balanced (M10).

It depends, because sometimes people who are thin are losing weight and affecting their health, because they do not eat right, but their weight is supposedly good (M07).

In the course of the interviews, the adolescents were asked to assess, in terms of healthy eating, their colleagues' daily eating habits, whom they spend most of the day with due to their school activities. In this respect, 20 alleged that, according to them, their friends do not eat healthily. Only two informed that their colleagues' diet was healthy, while five were undecided, dividing the group into friends who ate well and those who only ate "crap". In most cases, the justification the group indicated was based on the lack of time to eat well and the availability of healthy foods in school.

No, I am sure it isn't because in the canteen of my school, they only sell a lot of fatty things, and I see them eating every day (F05).

No because, in school, mainly, they're eating snacks with fat only all the time (M03)

It depends, but I have several friends in school who like to eat well, eat healthy things, do not drink soft drinks and like eating proteins to increase their muscle mass (M02). 
Some, because the others, as they spend a lot of time in the street and do not have time, do not mind what they eat (F06).

Yes, because most of them have energy, and I believe that a healthy diet means energy, and having energy I believe that he eats very well (M06).

At the end of the study, the adolescents were asked to assess whether their diet could change and, if yes, what foods they would like to consume and why they started to think like that. Thus, 26 adolescents were willing to change their habits in order to improve their health, with a view to reducing the consumption of fatty foods, such as crisps, hamburger, pizza, among others, and increase the consumption of fruits, vegetables and greens.

Yes, if I change, I'd cut the pasta, which I love, the things with fat, because everything I prepare contains a lot of oil, because I've already seen that it's bad because once I even gained weight [...] (F02).

Yes, eating more and better, eating fruits and vegetables, because that's the only way I won't have health problems further ahead (F01).

Yes, eating more salad and vegetables, to improve my health and my physical body (M10).

That's possible, I'd change everything, I'd stop drinking soft drinks, eating filled cookies, snacks and hamburger and I'd start to eat more vegetables and greens, because of my health, my skin and because of my family history (F06).

The adolescents are only able to change their habits when they acknowledge them and promote self-assessment and self-criticism. ${ }^{16}$ Thus, in the light of the results found, it can be assessed that the adolescents are critical towards their diet and aware that their attitudes, with regard to the present time, can entail drastic consequences for their future.

This thinking derives from the adolescents' observation of the people around them, based on situations in their daily family life and circle of friends. The genetic heritage plays a determinant role in some congenital illnesses and represents a risk element for several chronic illnesses, such as diabetes, osteoporosis, hypertension, cancer, obesity, among others. ${ }^{14}$ Therefore, socio-educational measures to prevent problems are extremely important.

Data indicate the frequent attachment to a diet that has been proven inappropriate as typi- cal eating habits of adolescents in recent years, as well as the use of food items that are easy to prepare and the skipping of meals, increasing the nutritional risk and the risk of illnesses in this age range. ${ }^{16}$

On the opposite, regarding the relations among food, weight and health, having energy as the meaning of complete health is compared with obesity as a mediator of diseases in adult life. In that sense, the excessive accumulation of body fat derives from an energetic disequilibrium. Different factors may be involved in this disequilibrium, including the lifestyle (diet and physical exercise), neuroendocrine alterations, together with a hereditary component. ${ }^{14}$

In this study, contents were identified that constitute social representations about the act of eating when the adolescents compare their attitudes and habits with those of their relatives and friends, tending towards the idealization that a high body weight is a synonym of impaired health.

In the interaction with the adolescents, in the care convergence phase, although the adolescents know the basic with a view to healthy eating, it was identified that they need further educational investments to incorporate it into their daily life. This can be explained by the fact that the adolescents consider that these problems are triggered in the long term and that, in general, they do not affect this age range.

Thus, health education should be understood as a training process of the adolescents for them to start acting consciously in view of the daily reality, building on previous experiences, always with a view to integration, continuity and progress in the social context they live in and also aiming for self-training to deal with fundamental problems of life and to plan their self-care.

In that sense, dietary and nutritional education in adolescence is aimed at the adoption of behaviors that improve health, through a series of learning experiences, modifying these behaviors to improve health.

\section{FINAL CONSIDERATIONS}

Inappropriate eating habits can cause both physical and psychological consequences, affecting the adolescents' health and quality of life. Not only inappropriate eating represents a problem, 
but also its consequences, which involve obesity and eating disorders, which have also been frequently assessed in studies involving adolescence, in line with the need for further knowledge on the topic.

The development of healthy eating habits in childhood has a great chance of turning into healthy eating habits in adult life. That explains the fundamental importance of teaching and encouraging correct eating for children and adolescents, and nursing plays an intermediating role in this process.

Nevertheless, the results have shown that the adolescents know about healthy eating and about the problems bad eating habits can cause for health. This matter is more related to the culture of these practices than to actual information, but it is highlighted that this understanding matters to plan and develop actions with this group in the problematization of the theme in health education strategies.

The moment of the interaction and discussions about the theme in the application phase of the CCR method offered contributions of great interest for the adolescents, as it made them debate ideas about the consumption of certain foods. In addition, the adolescents revealed their interest in modifying their eating based on the information provided in this respect, mainly regarding the risks of susceptibility to different diseases.

Based on the results, it is considered that nutrition is one of the main elements to promote human health and wellbeing, that the establishment of eating habits starts in childhood and is defined in adolescence and that these habits and customs will continue across the lifetime. Therefore, it is concluded that nursing should be an educating agent, making the adolescents turn into active subjects of their care, so as to acquire healthy eating habits and correct dietary practices.

Therefore, knowing the adolescents' representations about healthy eating contributes to unveil their knowledge and affections, providing support for the acceptance of adolescent health education actions in that group, arousing concerns and inquiries that lead them to criticism, reflection and action, with a view to changes of habits.

The sample did not permit showing significant differences in the results obtained between female and male adolescents. Therefore, it is identified that the expansion of the research with a larger number of subjects and the application of the analytic concept of gender in the search for male and female representation contents about the eating phenomenon can be an additional element for reflections about adolescent health.

\section{REFERENCES}

1. Organización Mundial de la Salud (OMS). La salud de los jóvenes: un reto y una esperanza. Geneva (CH); 1995.

2. Sá CP. A construção do objeto de pesquisa em representações sociais. Rio de Janeiro (RJ): EdUERJ; 1998.

3. Jodelet D. O movimento de retorno ao sujeito e a abordagem das representações sociais. Sociedade e Estado. Brasília. 2009 Set-Dez; 24(3):679-712.

4. Strauss LC. Introdução à obra de Marcel Mauss. In: Mauss M. Sociologia e antropologia. São Paulo (SP): Edusp; 1974. p.1-37.

5. Alves HJ, Boog MCF. Representações sobre o consumo de frutas, verduras e legumes entre fruticultores de zona rural. Rev Nutr. 2008 Nov-Dez; 21(6):705-15.

6. Leonardo M. Antropologia da alimentação. Rev Antropos. 2009 Dez: (3);1-6.

7. Marques JF, Silva KM, Moreira KAP, Queiroz MVO. Saúde e cuidado na percepção de estudantes adolescentes: contribuições para a prática de enfermagem. Cogitare Enferm. 2012 Jan-Mar; 17(1):37-43.

8. Moscovici S. Representações Sociais: investigações em psicologia social. $5^{\mathrm{a}}$ ed. Petrópolis (RJ): Vozes; 2009.

9. Sancovschi B. Sobre a noção de representação em S. Moscovici e F. Varela. Psico Sociedade. 2007; 19(2):7-14.

10. Paim L, Trentini M, Madureira VSF, Stamm M. Pesquisa convergente-assistencial e sua aplicação em cenários da enfermagem. Cogitare Enferm. 2008 Jul-Set; 13(3):380-6.

11. Antonacci MH, Pinho LB. Saúde mental na atenção básica: uma abordagem convergente-assistencial. Rev Gaúcha Enferm. 2011 Mar; 32(1):136-42.

12. Bardin L. Análise de conteúdo. Lisboa (PT): Edição 70; 2010.

13. Alves-Mazzotti AJ. Representações sociais: aspectos teóricos e aplicações à educação. Rev Múltiplas Leituras. 2008 Jan-Jun; 1(1):18-43.

14. Zancul MS. Orientação nutricional e alimentar dentro da escola: formação de conceitos e mudanças de comportamento [tese]. Araraquara (SP): Faculdade de Ciências Farmacêuticas, Universidade Estadual Paulista; 2008. 
15. Tomé G, Camacho I, Matos MG, Diniz JA. A influência da comunicação com a família e grupo de pares no bem-estar e nos comportamentos de risco nos adolescentes portugueses. Psicologia Reflexão
Crítica. 2011; 24(4):747-56.

16. Silva JG, Teixeira MLO, Ferreira MA. Alimentação e saúde: os sentidos atribuídos por adolescentes. Esc Anna Nery. 2012 Jan-Mar; 16(1):88-95.

25625-077 - Morin, Petrópolis, RJ, Brasil

E-mail: julyanagall@hotmail.com 